Journal of Economics and Management Strategy, 6:3, 497-527, 1997

\title{
Synergies in Wireless Telephony: Evidence from the Broadband PCS Auctions*
}

\author{
Lawrence M. Ausubel, Peter Cramton, R. Preston McAfee, and John McMillan
}

\begin{abstract}
We examine bid data from the first two broadband PCS spectrum auctions for evidence of value synergies. First, we estimate a benchmark regression for the determinants of final auction prices. Then, we include variables reflecting the extent to which bidders ultimately won or already owned the adjacent wireless properties. Consistent with geographic synergies in an ascending-bid auction, prices were higher when the highest-losing bidder had adjacent licenses. The footprints of winning bidders suggest that they were often successful in realizing these synergies.
\end{abstract}

JEL No.: D44 (Auctions), L96 (Telecommunications)

Keywords: Auctions, Multi-Object Auctions, Spectrum Auctions, Synergies, PCS

Send comments to:

$\begin{array}{llll}\text { Prof. Lawrence M. Ausubel } & \text { Prof. Peter Cramton } & \text { Prof. R. Preston McAfee } & \text { Prof. John McMillan } \\ \begin{array}{l}\text { Department of Economics } \\ \text { University of Maryland }\end{array} & \text { Department of Economics } & \text { Department of Economics } & \text { School of Intl Rel \& Pac Studs } \\ \text { College Park, MD 20742-7211 } & \text { College Park, MD 20742-7211 } & \text { Austin, TX 78712-1173 } & \text { La Jolla, CA 92093 } \\ \text { ausubel@econ.umd.edu } & \text { cramton@econ.umd.edu } & \text { mcafee@ mundo.eco.utexas.edu jmcmillan@ucsd.edu } & \text { Univ of California San Diego } \\ \text { (301) 405-3495 } & \text { (301) 405-6987 } & \text { (512) 475-8533 } & \text { (619) 534-5967 }\end{array}$

*We thank Ronald Harstad, Michael Rothkopf, and three referees for helpful comments, and the National Science Foundation for support. The authors advised various bidding firms and the FCC during the auctions; the views expressed are our own and not those of the companies we advised, nor of the FCC. We are grateful to Neile J. Quintero for expert research assistance. 



\title{
Synergies in Wireless Telephony: Evidence from the MTA Auction
}

\author{
Lawrence M. Ausubel, Peter Cramton, R. Preston McAfee, and John McMillan
}

Bidders are likely to be willing to pay more for two geographically contiguous PCS licenses than two equivalent non-contiguous licenses, and a single bidder may be willing to pay more for two licenses than would two separate bidders.

- FCC SECOND REPORT AND ORDER (1994, II91)

\section{Introduction}

A contentious issue in the design of the Federal Communications Commission (FCC) auctions of personal communications services (PCS) licenses concerned the importance of synergies. If large synergies are prevalent among the licenses being offered, then the simultaneous ascending auction mechanism the FCC adopted, which does not permit all-or-nothing bids on sets of licenses, might be expected to perform poorly. Bidders who must purchase multiple licenses to achieve value are exposed to the risk of ending up with an incomplete aggregation, and thus will be hesitant to bid aggressively. Such hesitation could result in low prices and an inefficient assignment of licenses. This article investigates the importance of local geographic synergies in the first two broadband PCS auctions. ${ }^{1}$ We find evidence that local synergies did affect the bidding, but no evidence that synergies failed to be achieved.

Synergies (or complementarities) among licenses may be conveniently classified as local or global. ${ }^{2} \mathrm{We}$ define local synergies as those gains in value that specifically arise from obtaining two or more geographically neighboring licenses. We define global synergies as those gains in value which accrue from obtaining increased numbers of licenses or markets: economies of scale or scope among multiple licenses which arise irrespective of their geographic locations. ${ }^{3}$

\footnotetext{
${ }^{1}$ On the form of the auctions, see Cramton (1997) and McAfee and McMillan (1996). The AB auction, which began on December 5, 1994 and ended on March 13, 1995, offered two $30 \mathrm{MHz}$ licenses (blocks A and B) in each of 51 geographic areas known as major trading areas, or MTAs, minus three licenses already awarded under a pioneer preference, for a total of 99 licenses for sale. The geographical extent of the MTAs is shown in Figure 1. In the C auction, which began on December 18, 1995 and ended on May 6, 1996, one $30 \mathrm{MHz}$ license (block C) was auctioned in each of 493 basic trading areas (BTAs). Each MTA consists of about 10 BTAs.

${ }^{2}$ Theoretical treatments of synergies in auctions include Bernheim and Whinston (1986), Gale (1990), Bykowsky, Cull, and Ledyard (1995), Jehiel, Moldovanu, and Stacchetti (1996), Krishna and Rosenthal (1997), Rosenthal and Wang (1995), Bikhchandani and Mamer (1995), Rothkopf, Pekec, and Harstad (1995), and Branco (1996).

${ }^{3}$ Our dichotomy between local and global is not meant to cover all synergies. Synergies also arise from a bidder's existing infrastructure. For example, a bidder may provide local telephone service in two nonadjacent regions and have a fiber-optic cable that
} 
Local synergies might be present for three reasons. First, consumers desire "seamless roaming," permitting them to use their telephones away from their home base. While seamless roaming can be arranged by contracts between independent providers, such contracts require coordination on a given technology and some management efforts. Second, there is a problem of boundary interference, requiring coordination of distinct PCS providers at the borders of their territories. Third, there may be local advertising and management economies of scale, in that advertisements may spill over license boundaries, and the efficient scale of regional management might be larger than a single license. Finally, local synergies may stem from increased market power.

Global synergies might occur because of scale economies in the deployment of PCS technology or in management of the network, or because consumers obtain higher values from PCS phones the more places their phones can be used. In addition, improved coordination in the pricing of the final services through multimarket contact (Parker and Roller 1996) might provide another source of global synergies. The apparent desire of three firms to provide a nationwide wireless service (see section 2, below) suggests that global synergies in PCS may exist (although it might simply be that local synergies are pervasive, and thus can only be fully achieved by a nationwide network). We examine global synergies by assessing whether firms with larger PCS winnings were willing to bid higher. However, our primary focus in this article is on local synergies.

The FCC's choice of auction form was controversial. Bykowsky et al. (1995, p. 5), for example, asserted that an "important feature of the PCS bidding environment is the existence of synergies from owning specific combinations of licenses. Because of these synergies, the value a bidder places on a particular PCS license will depend upon what other, for instance, geographically adjacent spectrum license it owns." They argued that the auction mechanism the FCC chose, with license-by-license bidding, could generate low revenue and an inefficient allocation. A bidder attempting to assemble a set of licenses might find that a single, critical license is necessary not only for its desired aggregation, but also for another firm's. In attempting to acquire this essential license, both firms are willing to pay more than the license's stand-alone, or individual, value. If synergies are large, the loser of a contest to acquire a critical license may find itself holding other licenses which, because the set is incomplete, are priced at more than their value. The risk of this ruinous outcome will make the bidders hesitant to bid aggressively to assemble their desired aggregation, and can lead to an inefficient allocation. Bykowsky et al. dubbed this phenomenon "mutually destructive bidding"; it is also referred to less dramatically as the "exposure problem." To prevent this, they suggested the FCC should have permitted package bidding (also known as combinational or combinatorial

connects the two regions. In this case, the bidder may value the two regions together at more than the sum of the individual valuations. 
bidding), where bidders can submit all-or-nothing bids for sets of licenses. In contrast, other commentators argued that local synergies would be realized by license-by-license bidding, and that the synergies were not so extreme and heterogeneous to warrant the added complexity of package bidding.

Synergies, therefore, have major implications for the design of spectrum-license and other multiple-object auctions. If synergies are extreme, package bidding may be warranted in order to overcome the exposure problem. But if synergies are modest, auctions with package bidding offer little advantage, and given the complexity of these auctions, the simultaneous ascending auction is probably the more practical design. ${ }^{4}$

Local synergies are arguably more important for the auction design than global synergies, because global synergies would seem less likely to give rise to an exposure problem. With local synergies, specific licenses are needed to make up complete license bundles; whereas with global synergies, the value of a license bundle reflects variables like the total population covered by the licenses in the bundle. Typically, realization of global synergies does not require a firm to acquire some other specific license, and thus the substitution possibilities available with global synergies are greater than with local synergies. The discontinuities in license values that give rise to the exposure problem therefore appear less severe with global synergies than with local synergies. ${ }^{5}$

In this article, we examine the auction prices for evidence of local synergies. Suppose that a bidder was expecting to realize greater value from a given license, because the bidder was also expecting to win a geographically adjacent license. The heightened willingness to pay would then be likely to be reflected in an unexplained high price, until the local synergy is controlled for. Thus, one hypothesis might be that the final prices of licenses would reflect the extent to which the winning bidders own or win geographically adjacent wireless properties. However, given the ascending-bid nature of the auction, the final price ought to reflect the value of the last bidder to drop out in the market. This marginal bidder would be willing to bid higher for the license if it expected to win adjacent licenses and if synergies were important. Hence, a second (and ultimately preferable) hypothesis might be that the final prices of licenses would reflect the extent to which the marginal (i.e., highest losing) bidders own or win adjacent properties.

In what follows, we first examine the determinants of the PCS auction prices using non-synergistic variables. We find that a simple model with six market variables provides a parsimonious account of the determinants of PCS prices. All of the variables have the predicted signs, and they explain a large portion of

\footnotetext{
${ }^{4}$ On the FCC's selection of licenses-by-license bidding over package bidding, see McMillan (1994). For a different situation - the scheduling of railroads - in which synergies are clearly so important that package bidding is needed, see Brewer and Plott (1996).

${ }^{5}$ On the other hand, if bidders were to view the acquisition of Los Angeles or New York as critical for offering "nationwide" service, then it would be possible for these to nevertheless give rise to an exposure problem.
} 
the variation in realized prices. We then introduce several distinct formulations of how local synergies might enter into the final auction price. In all of these formulations, a bidder holding an adjacent license is modeled as being willing to pay more for a given license. We construct variables associated with the extent to which the winning bidders hold neighboring licenses and the extent to which the marginal bidders hold neighboring licenses. The winning-bidder measures of synergy are found to be statistically insignificant. However, all of the marginal-bidder measures of synergy have the predicted positive sign and are statistically significant in both auctions. Therefore, it appears that local synergies are a significant factor in determining PCS prices.

Although local synergies are seen in the data, there is reason to expect that the synergies are modest, especially in the $\mathrm{AB}$ auction with MTA licenses. ${ }^{6}$ First, a bound on their importance is the cost of coordinating via contracts rather than operating adjacent regions within a single firm, and it would be surprising if this cost (which involves not only contracting costs but possibly lost scale economies) were very large for the MTAs. Second, the MTAs by design are large enough to minimize many of the local synergies. The MTA boundaries were drawn by Rand McNally (1994) to capture trading synergies. Thus, their very size and design insures that boundary interference problems usually arise in areas of low population density, and that there are few marketing spillovers across MTAs. The choice of MTAs by the FCC for the AB auction was in fact made in order that the license regions encompass local synergies.

With the much smaller BTA licenses offered in the $\mathrm{C}$ auction, one might have expected local synergies to be more important than in the $\mathrm{AB}$ auction. However, this is not found in our analysis of the auction prices. Firms were again willing to bid more when holding adjacent licenses, but the effect is no stronger than in the $\mathrm{AB}$ auction.

In a complementary article, Moreton and Spiller (1996) also empirically examine license interdependencies in the $\mathrm{AB}$ and $\mathrm{C}$ auctions. Similar to our findings, they conclude that auction participants were willing to bid more for a license "if it was adjacent to another license that they ultimately won in the auction, indicating the presence of local synergies between licenses" (Moreton and Spiller 1996, p. 2). They also report that a marginal bidder in the $\mathrm{C}$ auction tended to bid more when facing a winning bidder with nearby PCS acquisitions, and tended to bid less when facing a bidder with nearby cellular holdings. Taken together, our article and theirs provide good robustness checks on one another, as the explanatory variables in the two studies are defined somewhat differently, generated from different sources and analyzed differently, yet the two approaches reach similar conclusions. In

\footnotetext{
${ }^{6}$ Paul Milgrom and Robert Wilson, for example, in the Reply Comments of Pacific Bell to the FCC during the auction-design process, were notably skeptical of claims that local synergies would be so large as to generate severe exposure problems in the bidding.
} 
particular, our demographic variables are probably superior in that we include a variable representing the number of microwave incumbents requiring relocation, and we utilize the likely buildout area (as opposed to the gross land area) in calculating population density. Meanwhile, Moreton and Spiller's cellular synergy variables are probably superior, as they are constructed using county-level data (whereas ours are constructed using BTA-level data, and cellular boundaries do not coincide with BTA boundaries). Finally, the greatest divergence between the articles is the initial focus of Moreton and Spiller on attempting to explain the auction prices using various political economy variables, such as the political-party affiliations of the PUC commissioners in the relevant states. Our interpretation - although not necessarily theirs - of their regression results is that the political economy variables pale in significance to the demographic and synergy variables, and that political economy factors can be fairly said to have not played a major role in determining license prices.

A related empirical investigation of synergies is Gandal's (1995) study of the sequential auction of Israeli cable television licenses. Gandal finds evidence of local synergies for these licenses. However, these licenses cover regions that are only a tiny fraction of the size of BTAs. Moreover, the license boundaries in the Israeli auctions cross densely populated regions.

In the next section, we describe the bid data. The third section provides the benchmark model. The fourth tests for local synergies, and the fifth concludes.

\section{The Bid Data}

The details of the auctions are provided in Cramton (1997) and McAfee and McMillan (1996). We confine ourselves here to a discussion of the features of the auction outcomes salient for our investigation of local synergies.

In the $\mathrm{AB}$ auction, many bidders were ineligible to bid in certain regions because of cellular operations; the FCC forbade companies with cellular licenses in a given region from bidding for $30 \mathrm{MHz}$ PCS licenses in that region. This restriction created significant variation in competition across MTAs. In particular, with one exception, the Bell Operating Companies held cellular licenses in the areas of their wireline operations, and thus were ineligible to bid for PCS licenses in their home bases.

Several bidders had specific targets in the auction, associated with their existing infrastructure. Pacific Bell strongly desired to acquire licenses in Los Angeles and San Francisco, which would complement their 
existing wireline network in these regions. ${ }^{7}$ Ameritech and Bell South apparently desired PCS licenses in the neighborhood of their cellular and wireline operations. Powertel, which acquired licenses in Memphis, Birmingham, Jacksonville, appears to have followed a regional strategy consistent with the existence of local synergies.

Figure 1 shows the winning bidders in the $\mathrm{AB}$ auction. In addition, it shows the cellular/PCS footprints of three particular bidders: Ameritech, Western PCS, and American Portable. Ameritech's PCS winnings (dark red) clearly complement its cellular licenses (light red). Western PCS acquired licenses (dark yellow) adjacent to its cellular licenses (light yellow) in the West. In contrast, American Portable won licenses (dark green) that are disjoint, although three of the five licenses that American Portable won are adjacent to its cellular footprint (light green).

American Portable is a good example of a second group of bidders that did not appear to follow any particular geographically based strategy, nor were they seeking nationwide coverage. For American Portable, it does not appear that local synergies played a significant role in the acquisitions.

Figure 2 shows the footprints of the top-ten winners in the $\mathrm{C}$ auction. In the $\mathrm{C}$ auction, only small firms were eligible to participate. Hence, none of the C-block bidders had sizable cellular holdings; most were new entrants into the wireless communications business. ${ }^{8}$

Competition was much more intense in the $\mathrm{C}$ auction, presumably increasing the exposure problem. Nonetheless, several firms did acquire clusters of adjacent licenses in the $\mathrm{C}$ auction. The final footprints provide evidence that local synergies mattered and were often obtained. However, the bidding of the largest bidder, NextWave, suggests that local synergies were not overly decisive. NextWave pursued a strategy of acquiring major markets around the United States. Spending nearly $\$ 5$ billion, it possessed the resources to instead acquire large contiguous regions in a few parts of the country, but it chose not to do so. NextWave's strategy would not make sense if local synergies were large at the BTA level. ${ }^{9}$

\footnotetext{
${ }^{7}$ Pacific Bell was the only Bell Operating Company eligible to buy licenses in its wireline area, a consequence of the spinoff of its wireless division, AirTouch Communications, which joined with Bell Atlantic, Nynex and U.S. West to form PCS PrimeCo.

${ }^{8}$ Some of the bidders have ties to firms that do have cellular holdings. However, we do not have any way to assess the strength of these ties, and so ignore them. The auction rules explicitly exclude a cellular incumbent from exercising control of a bidder in the $\mathrm{C}$ auction.

${ }^{9}$ However, NextWave's ability to pursue a strategy of a few large regional clusters may have been hampered by the restriction that no bidder can hold more than $98 \mathrm{C}$ and F block licenses. Since NextWave was near this constraint, each license had a constant opportunity cost reflecting the FCC constraint. This may have discouraged NextWave from acquiring the small neighbors of its major markets.
} 
Three bidders in the $\mathrm{AB}$ auction, WirelessCo (a consortium of Sprint and three cable companies), AT\&T and PCS PrimeCo, announced an intention to provide a nationwide, or nearly nationwide, wireless communication service. All three acquired the licenses to do so. ${ }^{10}$ Both AT\&T and PCS PrimeCo owned considerable cellular holdings prior to the auction, while WirelessCo held cellular licenses in Richmond, Charlotte and Omaha, and was also forbidden to bid in Los Angeles because of member Cox's holding of the pioneer's preference license there. Figure 3 displays the cellular incumbency of WirelessCo in light gray, along with its acquisition of PCS licenses in dark gray. No pattern of license acquisition is apparent other than an absence of licenses along Interstate 75. WirelessCo was the first to introduce PCS service (in Washington, D.C., in November 1995).

AT\&T's cellular holdings (light gray) and PCS acquisitions (dark gray) are shown in Figure 4. The case for the importance of local synergies is somewhat better for AT\&T than for WirelessCo, in that AT\&T's holes tend to be clusters of several licenses rather than isolated single licenses, except for relatively expensive Indianapolis.

Figure 5 illustrates the extensive cellular holdings (light gray) and PCS acquisitions (dark gray) of PCS PrimeCo, the consortium of four Bell companies or wireless division. The missing licenses comprise a single connected region, providing the strongest evidence that local synergies dictated the choice of purchases.

Together, Figures 1-5 provide casual empirical evidence that local synergies played a role in the bidding decisions of several firms. The figures also suggest that the firms were often successful in piecing together large contiguous aggregations.

\section{The Benchmark Regression}

In this section, we investigate the extent to which we can explain the auction prices using non-synergistic variables. The resulting regression equations will then serve as our benchmark for studying the additional explanatory contribution of synergy variables, in Section 4.

Throughout our inquiry, the dependent variable is the winning dollar bid divided by the 1994 population of the market. For the three MTAs (New York, Los Angeles, and Washington) for which only the B-block license was auctioned, we utilize the B-block price; for the remaining MTAs, we use the average of the A- and B-block prices. Since industry participants consistently discuss wireless prices in terms of

\footnotetext{
${ }^{10}$ After the AB auction, according to the Wall Street Journal (March 14, 1995, p. A12), PrimeCo President George F. Schmitt said that his group expected to have a complete nationwide network operating within two years. Steven Hooper, chairman of AT\&T's mobile-telephone subsidiary, said, "This enables us to build a nationwide network."
} 
"\$/pop" (i.e., the dollar bid of the region divided by its population) - and since there are good reasons to believe that, ceteris paribus, the value of a license should be roughly proportional to the population it serves - we divide the final dollar bids by the estimated 1994 population. Empirically, the AB prices ranged from $\$ 0.60 /$ pop in Guam to $\$ 30.39 /$ pop in Chicago. The C prices (net of the $25 \%$ bidding credit) ranged from \$1.42 in Pittsburg, KS to \$74.85 in the US Virgin Islands. Because Alaska, Guam, and American Samoa are outliers in a number of dimensions, we drop them from our benchmark analysis, bringing the sample size to 48 in the $\mathrm{AB}$ auction and 487 in the $\mathrm{C}$ auction.

An alternative to our use of the winning bid as the dependent variable is to instead use the highestlosing bid. Given the ascending auction design, the marginal bidder with private values should be willing to bid up to its value before dropping out. Hence, absent jump bidding, the highest-losing bid should be no more than two bid increments below the marginal bidder's value and no greater than the marginal bidder's value. The winning bid should be no more than one bid increment below the marginal bidder's value and no greater than one bid increment above. Thus, the winning bid is a closer approximation to the marginal bidder's value.

The large discrepancy in prices between the $\mathrm{AB}$ and the $\mathrm{C}$ auctions suggests that the prices in these auctions do not reflect bidder values. However, what is important in our analysis is not whether prices match values in absolute terms, but in relative terms. The auction design encourages bidders to shift to licenses that represent better values. This tendency, which was clearly observed in the bidding, is likely to produce relative prices in line with relative valuations, even if budget constraints or a lack of competition prevent prices from matching true values.

Six variables were found to be useful for explaining prices in the $\mathrm{AB}$ and $\mathrm{C}$ auctions. The first of these variables represents the degree of competitiveness of the bidding for the particular license; the other five measure determinants of the inherent value of the license area to bidders. Several of the variables have enormous variation, suggesting a nonlinear relationship, so we use the logarithms of these variables in the benchmark regression (and all subsequent regressions). The explanatory variables are discussed below.

- Eligibility. As discussed earlier, telecommunications companies with significant cellular holdings in an MTA were ineligible to bid on the PCS licenses. The competitiveness of the bidding (and the ensuing price) for a particular MTA would be expected to depend on how many bidders were eligible; more than the raw number of eligible bidders, what would seem most important is the size of eligible bidders. Utilizing the upfront payment submitted by each bidder as a measure of size, we compute our explanatory variable by summing the upfront payments of all bidders who were eligible to bid on a 
particular MTA, and dividing this by the total upfront payments of all bidders in the auction. ${ }^{11}$ Observe that this variable was public information at the start of each auction and - as indicated in Table 1 - it varied from 0.305 to 0.809 in the $\mathrm{AB}$ auction. Because C-block bidders did not have significant cellular holdings, there were few instances of ineligibility in the $\mathrm{C}$ auction. Hence, for the $\mathrm{C}$ auction, this measure has a standard deviation only one-fifth as large as in the AB auction (ranging from .597 to $.860)$ and is likely to be less important.

- Population density. The per capita cost of providing wireless service should be expected to be decreasing in the population density of the market, since the cost of cell sites is spread over more customers. At the same time, wireless spectrum is more likely to become capacity-constrained - and, so, the PCS license is more likely to take on scarcity value - if the population density is greater. We utilize, as our explanatory variable, a measure of the population density of the natural buildout area (which omits sparsely populated locations), which was obtained from industry sources.

- Expected population growth. The value of a license in any market should obviously be expected to be increasing in the rate of population growth in that market, as growth increases both the future population and the future population density. Several measures of expected population growth were available. We take as our explanatory variable the measure that had the strongest predictive value: the expected growth in population from 1990 to 1999.

- Microwave links. These licenses do not come entirely unencumbered. Most PCS frequency blocks have existing microwave links, and PCS license-holders are obliged to bear the cost of relocating the microwave incumbents. Thus, license values should be decreasing in the number of existing microwave links. Unfortunately, we do not possess direct data on the number of existing links in the A- and B-blocks of spectrum. However, we possess a good proxy in the form of the number of existing microwave links (expressed per hundred million population) in the C-block of each BTA, which we take as our explanatory variable.

- Population. Large population centers may be more valuable, because of demand characteristics (commuting time, type of business, etc.). All other things being equal, high-population licenses sold for greater prices than low-population licenses. Even though prices are already expressed as $(\log ) \$ /$ pop, the (log) 1994 population retains statistical significance in the regression, and is used as an explanatory

\footnotetext{
${ }^{11}$ In the three pioneer-preference markets, in which one of the licenses was awarded before the auction, the mean upfront payment of the nationwide bidders is added, in order to correct for the fact that there is just a single license. Further, Pacific Bell is treated as only being eligible for licenses on the West Coast (even though it applied for all licenses), since it made clear before the auction began that it had no interest in acquiring licenses outside the West Coast.
} 
variable.

- Income. The value of a license should be expected to be increasing in household income, since wireless services have a positive income elasticity. Several measures of household income were available. Industry sources recommended utilizing the fraction of households with annual income exceeding $\$ 35,000$. This, in fact, had the strongest predictive value of all the income measures we tried, and we take this as our final explanatory variable.

The degree of bidding competition varied from license to license, in part because under the FCC's rules a firm already holding a cellular license was not permitted to bid for a PCS license in the same region. Thus Chicago was the only large-population region in which all three of the big AB bidders - AT\&T, WirelessCo, and PCS PrimeCo - were permitted to bid; and the two Chicago licenses were bid up to the highest price per pop of all licenses in the $\mathrm{AB}$ auction. The eligibility variable is included to capture this competitiveness effect. In one of our initial regressions for the $\mathrm{AB}$ auction, we also include a variable that accounts for the presence of a strong regional bidder. The "strong regional bidder" variable is assigned a value of one if any of GTE, PacTel, Bell South, or Ameritech prevailed in the bidding for either of the licenses for this MTA, and a value of zero, otherwise. Strong regional bidders brought deep pockets and focused interests to an MTA, tending to increase the auction price. ${ }^{12}$

For the $\mathrm{C}$ auction, we include two additional variables. The first is the log of the $\mathrm{AB}$ price. This variable is intended to account for variation in price that is not controlled for by the six variables. The second variable indicates whether a firm intending to use GSM technology won either the A or B license. Cblock bidders committed to GSM were less interested in licenses in these MTAs, since they would not add to the GSM footprint. Hence, competition (and prices) should be less in markets that already have a GSM provider from the $\mathrm{AB}$ auction.

Summary statistics for the variables in our benchmark regressions are displayed in Tables 1 and 2.

The results of our benchmark price regression for the $\mathrm{AB}$ auction are displayed in column (1) of Table 3. All of the coefficients have the expected sign, and most are significant at the 5\% level. The only variable whose inclusion seems questionable is the income variable, which has a t-statistic of only 1.0. However, we choose to include it here, on account that in alternative specifications (for example, column (2), which includes Alaska, Guam and American Samoa), the coefficient approaches significance. Observe that the estimation appears robust both to including the three smallest-population MTAs (column 2) and to

\footnotetext{
${ }^{12}$ The strong regional bidder variable is admittedly ad hoc. A better approach would be to construct a continuous variable that captures the extent of the winning or marginal bidder's wireline network within the license area. Unfortunately, we do not have this data.
} 
weighting the observations by (log of) 1994 population (column 3). If strong regional winner is added to the regression equation, its coefficient is positive and is also significant at the 5\% level (column 4).

Moreover, the six basic explanatory variables go a long way toward explaining the variation in prices. The baseline regression of column (1) has an adjusted $R^{2}$ of 0.60 . The adjusted $R^{2}$ for the variations on the regression in columns (2)-(5) attain values as high as 0.74 . Without inclusion of any variables to account for geographic synergies, we gain a great deal of insight into the determination of $\mathrm{AB}$ prices. ${ }^{13}$

One potential omitted variable in our regression is a proxy for differences in the cost of building the network due to variations in the terrain. Flat areas like Chicago are cheaper to build out than the hilly terrain in the Charlotte MTA. Since terrain is likely to vary in a continuous fashion, this and other geographically based omitted variables may cause "spatial" correlation of errors, which is analogous to serial correlation in time series analysis. To test for the importance of spatial correlation, we include in column (5) spatially correlated errors. This is the population weighted average error in the regression for the markets adjacent to the particular market (we iterate the regression until the average errors converge). If omitted variables (like terrain) that change continuously in geography are critical, then spatially correlated errors should have a positive and significant coefficient. The fact that the variable is insignificant suggests that we have not omitted a critical variable. ${ }^{14}$ Another test for spatial correlation is the Moran I test (Anselin 1988, pp. 101-2). The test statistic is $.147<1.96$, so we cannot reject the null hypothesis of no spatial correlation at the $5 \%$ level.

Table 4 gives the benchmark regression for the $\mathrm{C}$ auction. The results are similar to the $\mathrm{AB}$ auction. However, as expected, eligibility is less important. In addition, the number of microwave links per hundred million people does not significantly affect price. The size of the market is the strongest determinant of price. Overall, the regressors explain substantially less of the variation than in the AB auction. These results

\footnotetext{
${ }^{13}$ However, we speculate in the conclusion that the strong positive coefficient on (log) 1994 population may itself be a reflection of synergies. It may be the case that holding large population-centers may be the key to realizing synergies, which is one interpretation why high-population MTAs sold for greater prices than low-population MTAs. (But the reader should be cautious here: this might also simply reflect that population-centers - in isolation -- are inherently more valuable.)

It is also reasonable to speculate that the positive coefficient on the strong regional winner variable is itself a reflection of a geographical synergy between the regional bidder's existing wireless or wire telephone infrastructure and the acquired PCS license. (Again the reader should be cautious here: the interest of a regional bidder could simply reflect a desire to limit the number of competitors in or near its current operating region.)

${ }^{14}$ The spatially correlated errors variable is subject to several interpretations, one of which is synergies. With local synergies, borders between regions held by distinct firms may be bid up, since these borders represent the contested properties; the interior of the regions may have low prices. This would result in a positive coefficient for the variable.
} 
are robust to including all markets, to weighting the data by log population, and to dropping the technology and MTA price variables. The spatially correlated errors coefficient is positive and significant. Similarly, the Moran I test for spatial correlation is $6.81>1.96$, so we reject the null hypothesis of no spatial correlation at the 5\% level. Prices of neighboring BTAs are positively correlated after controlling for differences in the BTAs, suggesting a geographically based omitted variable.

In the $\mathrm{AB}$ auction and especially the $\mathrm{C}$ auction, there was substantial unexplained variation in prices across markets. The issue we explore in the next section is the extent to which local synergies accounted for this unexplained variation.

\section{Synergies}

To assess the importance of local synergies, we must first define measures of these synergies. We consider a number of different indices. These measures differ along three dimensions. First, it is unclear whether local synergies should be calculated from a firm's PCS footprint, or whether it should be calculated from the firm's entire wireless (PCS acquisitions plus cellular holdings) footprint. Our first and third indices look at only the PCS footprint, while our second and fourth indices include all of the firm's wireless holdings. ${ }^{15}$ Second, it is unclear whether synergies should be gauged by looking at the absolute or the relative population of adjacent ownership. Our first and second measures take an absolute approach, utilizing the sum of the surrounding populations held by the same firm. Our third and fourth measures take a relative approach, calculating the proportion of surrounding MTA populations that are owned by a given firm. This approach assumes that the synergistic enhancement to a market's value is directly proportional to the (population-weighted) fraction of the surrounding region held by the same company. Third, it is unclear whether synergies should be assessed for the marginal bidders (the last to drop out) or the winning bidders, so we report results using variables constructed each way.

Consider any market $i$, and let $N_{i}$ denote the set of neighbors for market $i$. Since, in an ascending-bid auction, the price reflects the valuation of the marginal bidder (the last bidder to drop out), many of our synergy measures are based on the extent to which the marginal bidder wins or already owns adjacent markets. $w_{i j}$ is an indicator variable for the marginal bidder in market $i$ winning a PCS license in market ${ }_{j} 0 N_{i}$; $W_{i j}$ is the analogous indicator for the marginal bidder in market $i$ holding either PCS or cellular in

\footnotetext{
${ }^{15}$ An alternative would be to treat PCS and cellular holdings separately. This may be preferable, since cellular holdings and any associated synergies are ex ante observable, whereas PCS holdings are endogenously determined at auction. However, even well before the end of the auction, the ascending-bid design reveals to bidders accurate information about who is likely to win what (Cramton 1997). Hence, this distinction between PCS and cellular holdings may not be too important. See Moreton and Spiller (1996) for an analysis using this alternative approach. This change does not alter the basic results.
} 
market $j$.

Our approach to quantifying local synergies may be motivated as follows. Suppose that the primary source of synergies is the availability of "seamless roaming." Then it is plausible that the synergy gain, $S_{i j}$, associated with acquiring a wireless license for market $i$ if one already owns a wireless license for market $j$ is directly proportional to the population, $p_{i}$, of market $i$, since this is indicative of the number of roamers. It is also plausible that $S_{i j}$ is directly proportional to the population, $p_{j}$, of market $j$, since this is indicative of the number of places to roam. Thus, we may sensibly specify:

$$
S_{i j}=\beta \delta_{i j} p_{i} p_{j},
$$

for some constant $\beta>0$, where $\delta_{i j}=1$, if markets $i$ and $j$ are adjacent, and $\delta_{i j}=0$, otherwise. ${ }^{16}$ Expressed in terms of dollars per unit of population, license $i$ increases the firm's value by an amount proportional to the population of market $j$, and vice versa. The synergy gain per pop, $s_{i}$, associated with license $i$ is then given by:

$$
s_{i}=\beta \sum_{j \in N_{i}} p_{j} w_{i j} .
$$

For the empirical work that follows, we use the logarithm of price as our dependent variable; in order to avoid taking the log of zero, we define the following absolute synergy variables for the marginal bidder:

- Absolute local synergy excluding cellular footprint:

$$
a_{i}=\log \left(1+\sum_{j \in N_{i}} p_{j} w_{i j}\right) .
$$

This variable measures the absolute population of neighboring licenses to $i$ for which the marginal bidder wins a PCS license.

- Absolute local synergy including cellular footprint:

$$
A_{i}=\log \left(1+\sum_{j \in N_{i}} p_{j} W_{i j}\right) .
$$

This variable measures the absolute population of neighboring licenses to $i$ for which the marginal bidder

\footnotetext{
${ }^{16}$ The alert reader may observe that the form of synergies posited in this equation is similar to that assumed in "gravity models" of international trade. As Alonso (1987) notes in his review, the gravity-model formulation of taking the product of the two respective regions' populations is "unconventional and to a degree bizarre" and "not based on well-specified theory" (p. 561). Nevertheless, this formulation in wireless telephony is motivated by the desirability of "seamless roaming" and, as we shall see below, the implied absolute measure of synergy performs the best, empirically, of all the measures we have tried.
} 
either already owns a cellular license or wins a PCS license.

An alternative measure of synergies is "relative": the population-weighted proportion of surrounding regions in which the marginal bidder wins or already owns licenses.

- Relative local synergy excluding cellular footprint:

$$
r_{i}=\frac{\sum_{j \in N_{i}} p_{j} w_{i j}}{\sum_{j \in N_{i}} p_{j}} .
$$

This variable measures the percentage of the population of neighboring licenses to $i$ for which the marginal bidder wins a PCS license.

- Relative local synergy including cellular footprint:

$$
R_{i}=\frac{\sum_{j \in N_{i}} p_{j} W_{i j}}{\sum_{j \in N_{i}} p_{j}} .
$$

This variable measures the percentage of the population of neighboring licenses to $i$ for which the marginal bidder either already owns a cellular license or wins a PCS license.

Each of these measures is likely to be larger when the marginal bidder is larger (wins more PCS or holds more cellular licenses). Hence, it is possible that the local synergy variable is picking up global synergies. To avoid this problem, we also include the total dollar winnings of the marginal bidder as a measure of global synergies.

Analogous measures of synergies can also be defined with reference to the winning bidders, as opposed to the marginal bidders. However, given the ascending-bid auction design, the final price should reflect the valuation (including any synergies) of the marginal bidder. Hence, the synergy measure based on the marginal bidder is preferred. Nonetheless, the measure based on the winning bidder is of interest, because it tells us the extent to which the winner had to pay a premium to secure a package of adjacent licenses.

Table 5 provides summary statistics for each of our synergy variables.

Table 6 gives the price regressions in the $\mathrm{AB}$ auction when the various synergy variables are included. Column (1) repeats the benchmark model without any synergy variables. The next four columns add one synergy variable at a time to the regression equation. All four of the synergy variables based on the marginal bidder are positive and significant. ${ }^{17}$ From this table, we conclude that the marginal bidder pushed prices

\footnotetext{
${ }^{17}$ As a further test of the robustness of these results we looked at two other measures of synergies. The simplest was an indicator
} 
higher in situations where the marginal bidder held or ultimately won adjacent properties. This is strong evidence of local synergies. When we base the local synergy measure on whether the winning bidder held or won adjacent licenses (columns 6-7), we get a negative and insignificant coefficient. Hence, despite the presence of local synergies, the winning bidders did not have to pay a premium to acquire adjacent licenses, unless the marginal bidder would also have realized synergies.

Our measure of global PCS synergies is the dollar winnings of the marginal bidder. Contrary to the presence of global synergies, this coefficient is negative (though borderline insignificant) in all specifications. However, one must be careful in interpreting this coefficient. Ausubel and Cramton (1996) show that large bidders have the greatest incentive to strategically reduce demand in order to keep prices low. Thus, large bidders might empirically drop out early, despite global synergies. Indeed, Moreton and Spiller (1996) find significant global synergies from cellular holdings. (A firm's pre-auction holdings should not give rise to the incentive to strategically reduce demand.)

Table 7 presents the price regressions in the $C$ auction including synergy variables. Since none of the bidders in the $\mathrm{C}$ auction are significant cellular incumbents, there are just two measures of synergies for a marginal bidder. Both synergy measures enter positive and significant (columns 2-3), suggesting local synergies. However, the estimated coefficient (.016) on the absolute synergy variable is smaller than the comparable estimates (.030 and .033) from the AB auction. Similarly, the coefficient (.385) on the relative synergy measure is smaller than the comparable estimates (.886 and .679) from the $\mathrm{AB}$ auction. In the $\mathrm{C}$ auction, there is evidence of local synergies, but the evidence is not as strong as in the AB auction. When synergies are measured by the winning bidder (columns 4-5), there is at best a borderline-significant effect. As in the $A B$ auction, prices were increased by the extent to which the marginal bidders had adjacent properties, but not by the extent to which the winning bidders had adjacent properties. Finally, the coefficient on the dollar winnings of the marginal bidder is statistically insignificant, as well as much smaller in magnitude than the corresponding coefficient from the $\mathrm{AB}$ auction, providing no evidence that large bidders tended to drop out early or late (i.e., there is no evidence from the regressions that demand reduction dominated global synergies - or the reverse - in the $\mathrm{C}$ auction).

\section{Conclusion}

We find synergies deriving from geographic adjacency in the first two broadband PCS auctions.

equal to 1 if the marginal bidder held or won an adjacent license. The results were similar but slightly weaker with this coarser measure. The second attempted to refine the measure by basing it on the population near the border of the market. Specifically, we counted population of all cities over 50 thousand within 100 miles of the market border. The results were similar. 
Explanatory variables embodying auction competitiveness, population, expected population growth, population density, and incumbent microwave users are strongly significant and have coefficients of the expected signs. The preferred local-synergy variables were also significant in all specifications. The marginal bidder bid higher in situations where it held or ultimately won licenses in adjacent markets.

We obtained two other results consistent with the existence of local synergies in a limited sense. First, the "strong regional bidder" variable, when added to the benchmark regression in the AB auction, had a strong and significant positive coefficient. One interpretation of this result is that regional bidders realized synergies by acquiring properties near to their existing local service areas. But note that, for PacTel, the existing local service was conventional landline - as opposed to wireless - and the same was, in part, true for Ameritech and Bell South. Second, even though population has been divided out of the dependent price variable, population remains borderline-significant in the $\mathrm{AB}$ auction and highly significant in the $\mathrm{C}$ auction. One interpretation of this result is that bidders derive positive synergies from serving large population areas: large markets are the keys to realizing synergies. But this empirical finding might also merely reflect that large population centers are inherently more valuable, even if held on their own.

Surprisingly, local synergies do not appear to be stronger in the $\mathrm{C}$ auction than in the AB auction. Since the BTAs in the $\mathrm{C}$ auction are only about one-tenth the size of the MTAs in the AB auction, BTA boundaries are more apt to cross high-population areas and divide common media markets (such as the Washington and Baltimore BTAs). Hence, one would have expected geographic synergies to be stronger between BTA than MTA markets. One explanation is that the $\mathrm{C}$ block bidders were less willing to bid for synergies, since they faced a more severe exposure problem, due to the much greater competition and smaller markets in the $\mathrm{C}$ auction. However, this seems implausible given that prices in the $\mathrm{C}$ auction were about $80 \%$ higher than in the $\mathrm{AB}$ auction, netting out the value of bidding credits and installment payments. An alternative interpretation is that our functional forms are imperfectly capturing local synergies, especially in the $\mathrm{C}$ auction.

From a policy perspective, our analysis suggests that the FCC made the right choice of auction mechanism in adopting license-by-license bidding rather than package bidding. Bidders in the $\mathrm{AB}$ and $\mathrm{C}$ auctions had local synergies and bid for them. Judging from the footprints, they were often successful. Apparently, the local synergies were not so large that bidders faced a serious exposure problem. This is further supported by the absence of bid withdrawals intended to back out of failed aggregations.

On the other hand, some small companies may have been discouraged from bidding in the $\mathrm{AB}$ auction because of the large size of the MTAs. This was the motivation for auctioning the second half of the broadband PCS spectrum as BTAs. Certainly, competition in the first BTA auction was much more intense than in the MTA auction. However, the small bidders were attracted to the $\mathrm{C}$ auction not only by the small 
license size, but also by favorable installment payment terms and the fact that large firms were excluded from bidding. ${ }^{18}$ Indeed, competition in the second BTA auction for blocks D, E, and F was similar to the AB auction, rather than the $\mathrm{C}$ auction. Market size alone cannot explain the differences in competition.

We conclude that local synergies were a significant determinant of prices in the $\mathrm{AB}$ and $\mathrm{C}$ auctions. The bidding data show (1) bidders believed that local synergies were present, (2) bidders were willing to pay more for them, and (3) synergies were reflected in price to the extent that the marginal - not the winning - bidder would realize them.

\section{References}

Alonso, William (1987), "Gravity Models," in John Eatwell et al. (eds.), The New Palgrave: A Dictionary in Economics, New York: Stockton Press, 2, 561-562.

Anselin, Luc (1988), Spatial Econometrics: Methods and Models, London: Kluwer Academic.

Ausubel, Lawrence M. and Peter C. Cramton (1996), "Demand Reduction and Inefficiency in Multi-Unit Auctions," Working Paper No. 96-07, University of Maryland.

Bernheim, B. Douglas and Michael D. Whinston (1986), "Menu Auctions, Resource Allocation and Economic Influence," Quarterly Journal of Economics, 101, 1-31.

Bikhchandani, Sushil and John W. Mamer (1996), "Competitive Equilibrium in an Exchange Economy with Indivisibilities," Working Paper, UCLA.

Branco, Fernando (1996), "Multi-Object Auctions with Synergies," Working Paper, Universidade Catolica Portuguesa.

Brewer, Paul and Charles R. Plott (1996), “A Binary Conflict Ascending Price Mechanism for the Decentralized Allocation of the Right to Use Railroad Tracks," International Journal of Industrial Organization, forthcoming.

Bykowsky, Mark M., Robert J. Cull, and John O. Ledyard (1995), "Mutually Destructive Bidding: The FCC Auction Design Problem," Working Paper, CalTech.

Cramton, Peter (1997), “The FCC Spectrum Auctions: An Early Assessment,” Journal of Economics and Management Strategy, forthcoming.

Federal Communications Commission (1994), Second Report and Order, FCC 94-61, Washington, DC.

Gale, Ian (1990), “A Multi-Object Auction with Superadditive Values,” Economic Letters, 34, 323-328.

Gandal, Neil (1997), "Sequential Auctions of Interdependent Objects: Israeli Cable Television Licenses,” Journal of Industrial Economics, forthcoming.

Jehiel, Philippe, Benny Moldovanu and Ennio Stacchetti (1996), "Multidimensional Mechanism Design for Auctions with Externalities," Working Paper, University of Michigan.

Krishna, Vijay and Robert Rosenthal (1997), "Simultaneous Auctions with Synergies," Games and Economic Behavior, forthcoming.

\footnotetext{
${ }^{18}$ Recent theoretical work on multi-object auctions makes clear the importance of demand reduction by large bidders in the determination of auction outcomes (Ausubel and Cramton 1996). Thus, the participation of many small bidders could have a dramatic effect in increasing auction revenues.
} 
McAfee, R. Preston and John McMillan (1996), “Analyzing the Airwaves Auction,” Journal of Economic Perspectives, 10, 159-176.

McMillan, John (1994), “Selling Spectrum Rights,” Journal of Economic Perspectives, 8, 145-162.

Moreton, Patrick S. and Pablo T. Spiller (1996), "What's in the Air? Interlicense Synergies and Their Impact on the FCC's Broadband PCS License Auctions," Working Paper, UC Berkeley.

Parker, Philip and Lars-Hendrick Roller (1996), "Collusive Conduct in Duopolies: Multimarket Contact and CrossOwnership in the Mobile Telephone Industry," Working Paper, INSEAD.

Rand McNally Inc. (1994), Commercial Atlas and Marketing Guide, Chicago: Rand McNally.

Rosenthal, Robert W. and Ruqu Wang (1995), "Simultaneous Auctions with Synergies and Common Values," Working Paper, Boston University.

Rothkopf, Michael H., Aleksandar Pekec, and Ronald M. Harstad (1995), "Computationally Manageable Combinatorial Auctions," Working Paper, Rutgers University. 
TABLE 1. SUMMARY STATISTICS FOR AB AUCTION

\begin{tabular}{rrrrr}
\hline \hline Variable & Mean & Std Dev & Min & Max \\
\hline Log of price (\$ per person in 1994) & 2.443 & 0.596 & 1.053 & 3.414 \\
Eligible bidders upfronts/total upfronts ${ }^{1}$ & 0.612 & 0.119 & 0.305 & 0.809 \\
Log population density of buildout area & 6.492 & 0.807 & 3.364 & 8.402 \\
Ten-year population growth 1990 to 1999 & 0.114 & 0.060 & 0.007 & 0.234 \\
Microwave links/hundred million people 1994 & 0.092 & 0.079 & 0.003 & 0.330 \\
Log of 1994 population & 15.250 & 0.713 & 13.956 & 17.104 \\
Fraction of households with annual income > \$35k & 0.511 & 0.089 & 0.109 & 0.706 \\
Strong regional bidder & 0.208 & 0.410 & 0.000 & 1.000 \\
Spatially correlated errors & -0.023 & 0.175 & -0.447 & 0.315 \\
\hline \hline
\end{tabular}

Notes: Excluding Alaska, Guam, and American Samoa. Sample size is 48. Bid data are from ftp.fcc.gov.

Market data are from various industry sources.

${ }^{1}$ Sum of upfront payments for bidders eligible to bid in market over total upfront payments. In pioneer markets, the mean upfront payment of the nationwide bidders is added to account for the single license.

${ }^{2}$ Population density is measured in the natural buildout area, ignoring sparsely populated regions.

${ }^{3}$ Microwave links per hundred million people in $\mathrm{C}$ frequency block. This is highly correlated with microwave links in the A-B frequency blocks.

TABLE 2. SUMMARY STATISTICS FOR C AUCTION

\begin{tabular}{rrrrr}
\hline \hline Variable & Mean & Std Dev & Min & Max \\
\hline Log of price (\$ per person in 1994) & 2.870 & 0.729 & 0.349 & 4.316 \\
Eligible bidders upfronts/total upfronts & 0.824 & 0.022 & 0.597 & 0.860 \\
Log population density of buildout area & 5.362 & 1.423 & 1.454 & 8.779 \\
Ten-year population growth 1990 to 1999 & 0.098 & 0.089 & -0.190 & 0.494 \\
Microwave links/hundred million people 1994 & 0.148 & 0.228 & 0.000 & 1.909 \\
Log of 1994 population & 12.394 & 1.084 & 10.203 & 16.721 \\
Fraction of households with annual income > \$35k & 0.467 & 0.086 & 0.095 & 0.753 \\
Log of MTA price (\$ per person in 1994) & 2.440 & 0.587 & 1.053 & 3.414 \\
GSM technology in MTA & 0.497 & 0.501 & 0.000 & 1.000 \\
Spatially correlated errors & -0.029 & 0.186 & -0.729 & 0.490 \\
\hline \hline
\end{tabular}

Notes: Excluding Alaska, Guam, and American Samoa. Sample size is 487. 
TABLE 3. BENCHMARK PRICE REGRESSION FOR AB AUCTION

\begin{tabular}{|c|c|c|c|c|c|}
\hline \multirow[b]{2}{*}{ Variable } & \multicolumn{5}{|c|}{ Log of Price (\$ per person in 1994) } \\
\hline & (1) & (2) & (3) & (4) & $(5)$ \\
\hline Eligible bidders'upfronts/total upfronts & $\begin{array}{l}2.345 \\
(4.84)\end{array}$ & $\begin{array}{l}2.422 \\
(5.14)\end{array}$ & $\begin{array}{l}2.330 \\
(4.82)\end{array}$ & $\begin{array}{l}2.770 \\
(5.60)\end{array}$ & $\begin{array}{l}2.378 \\
(4.75)\end{array}$ \\
\hline Log population density of buildout area & $\begin{array}{l}0.237 \\
(2.70)\end{array}$ & $\begin{array}{l}0.276 \\
(4.27)\end{array}$ & $\begin{array}{l}0.236 \\
(2.66)\end{array}$ & $\begin{array}{l}0.263 \\
(3.13)\end{array}$ & $\begin{array}{l}0.231 \\
(2.56)\end{array}$ \\
\hline Ten-year population growth 1990 to 1999 & $\begin{array}{l}3.718 \\
(3.65)\end{array}$ & $\begin{array}{l}3.765 \\
(3.88)\end{array}$ & $\begin{array}{l}3.722 \\
(3.64)\end{array}$ & $\begin{array}{l}3.294 \\
(3.35)\end{array}$ & $\begin{array}{l}3.764 \\
(3.62)\end{array}$ \\
\hline Microwave links/hundred million people 1994 & $\begin{array}{l}-2.052 \\
(2.47)\end{array}$ & $\begin{array}{r}-1.884 \\
(2.35)\end{array}$ & $\begin{array}{l}-2.052 \\
(2.43)\end{array}$ & $\begin{array}{r}-1.643 \\
(2.03)\end{array}$ & $\begin{array}{l}-2.102 \\
(2.45)\end{array}$ \\
\hline Log of 1994 population & $\begin{array}{l}0.187 \\
(1.90)\end{array}$ & $\begin{array}{l}0.148 \\
(1.95)\end{array}$ & $\begin{array}{l}0.181 \\
(1.84)\end{array}$ & $\begin{array}{l}0.153 \\
(1.62)\end{array}$ & $\begin{array}{l}0.188 \\
(1.90)\end{array}$ \\
\hline Fraction of households with annual income $>\$ 35 \mathrm{k}$ & $\begin{array}{c}0.679 \\
(1.00)\end{array}$ & $\begin{array}{l}0.963 \\
(1.60)\end{array}$ & $\begin{array}{l}0.678 \\
(0.99)\end{array}$ & $\begin{array}{l}0.559 \\
(0.87)\end{array}$ & $\begin{array}{l}0.642 \\
(0.92)\end{array}$ \\
\hline Strong regional winner & & & & $\begin{array}{l}0.350 \\
(2.35)\end{array}$ & \\
\hline Spatially correlated errors & & & & & $\begin{array}{r}-0.106 \\
(0.31)\end{array}$ \\
\hline Constant & $\begin{array}{r}-3.960 \\
(2.74)\end{array}$ & $\begin{array}{r}-3.834 \\
(4.04)\end{array}$ & $\begin{array}{l}-3.862 \\
(2.68)\end{array}$ & $\begin{array}{r}-3.881 \\
(2.83)\end{array}$ & $\begin{array}{c}-3.954 \\
(2.71)\end{array}$ \\
\hline Data weighted by log 1994 population & No & No & Yes & No & No \\
\hline Include Alaska, Guam, and American Samoa & No & Yes & No & No & No \\
\hline Sample size & 48 & 51 & 48 & 48 & 48 \\
\hline Adjusted $\mathrm{R}^{2}$ & 0.599 & 0.738 & 0.594 & 0.639 & 0.590 \\
\hline
\end{tabular}

Notes: t-statistics in parenthesis. 
TABLE 4. BENCHMARK PRICE REGRESSION FOR C AUCTION

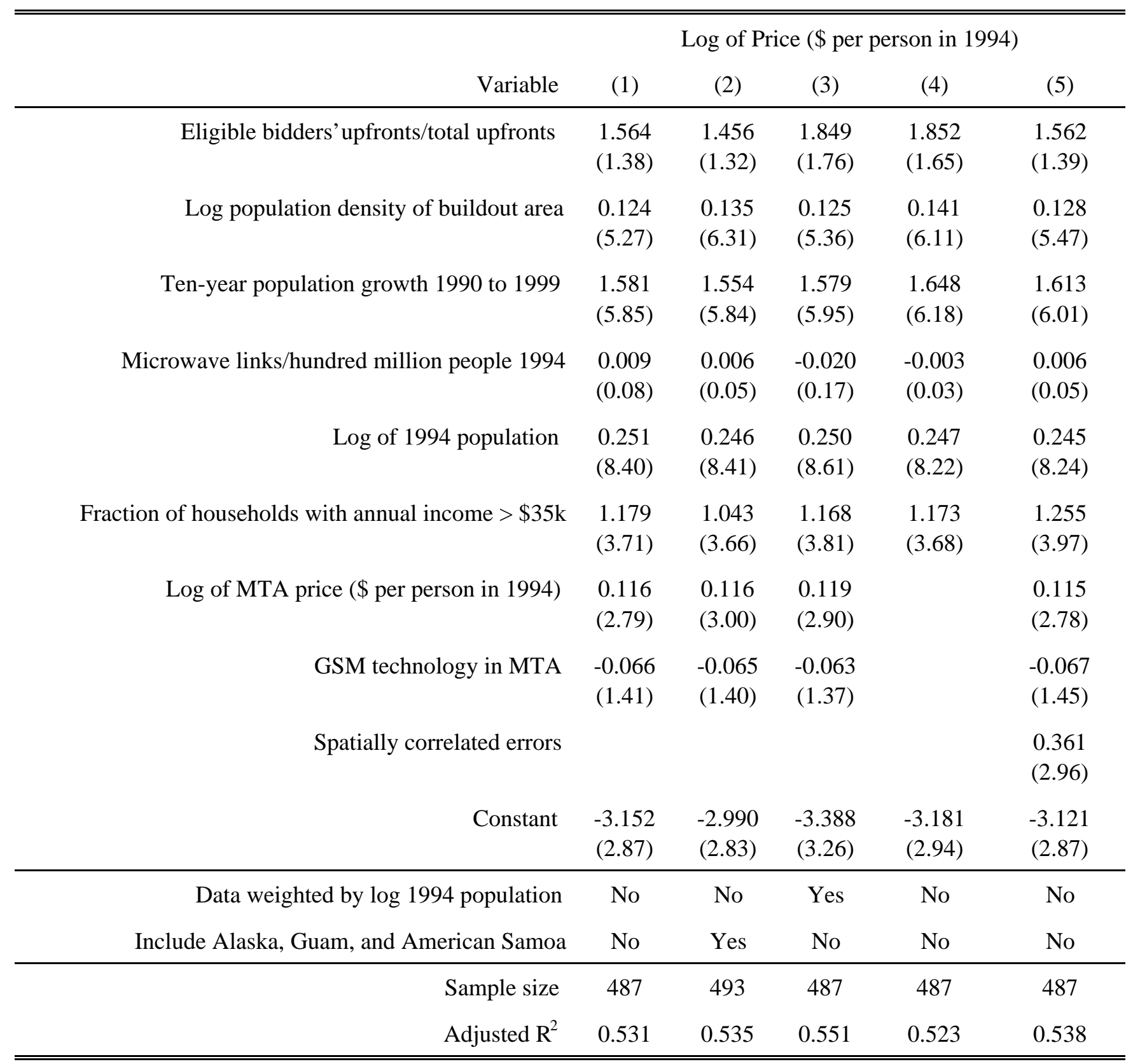

Notes: t-statistics in parenthesis. 
TABLE 5. SUMMARY STATISTICS FOR SYNERGY VARIABLES

\begin{tabular}{|c|c|c|c|c|}
\hline Variable & Mean & Std Dev & Min & Max \\
\hline Dollar winnings of marginal bidder (AB) & 0.564 & 0.761 & 0.000 & 2.200 \\
\hline (C) & 0.576 & 1.229 & 0.000 & 4.201 \\
\hline Dollar winnings of winning bidder (AB) & 1.294 & 0.510 & 0.000 & 2.200 \\
\hline$(\mathrm{C})$ & 0.720 & 1.327 & 0.000 & 4.201 \\
\hline Absolute synergy of marginal bidder excluding cellular (AB) & 5.977 & 7.813 & 0.000 & 17.259 \\
\hline (C) & 5.292 & 6.515 & 0.000 & 16.795 \\
\hline Absolute synergy of marginal bidder including cellular (AB) & 8.054 & 8.121 & 0.000 & 17.525 \\
\hline Relative synergy of marginal bidder excluding cellular (AB) & 0.180 & 0.296 & 0.000 & 1.000 \\
\hline (C) & 0.133 & 0.250 & 0.000 & 1.000 \\
\hline Relative synergy of marginal bidder including cellular (AB) & 0.303 & 0.365 & 0.000 & 1.000 \\
\hline Absolute synergy of winning bidder excluding cellular (AB) & 9.560 & 5.327 & 0.000 & 16.741 \\
\hline (C) & 10.167 & 5.904 & 0.000 & 16.826 \\
\hline Absolute synergy of winning bidder including cellular (AB) & 12.922 & 5.183 & 0.000 & 17.176 \\
\hline Relative synergy of winning bidder excluding cellular (C) & 0.314 & 0.336 & 0.000 & 1.000 \\
\hline
\end{tabular}

Notes: Excluding Alaska, Guam, and American Samoa. Sample size is 48 in AB auction and 487 in C auction. 
TABLE 6. PRICE REGRESSION INCLUDINGSYNERGIES FOR AB AUCTION

\begin{tabular}{|c|c|c|c|c|c|c|c|}
\hline \multirow[b]{2}{*}{ Variable } & \multicolumn{7}{|c|}{ Log of Price (\$ per person in 1994) } \\
\hline & (1) & (2) & (3) & (4) & (5) & (6) & (7) \\
\hline Eligible bidders' upfronts/total upfronts & $\begin{array}{l}2.345 \\
(4.84)\end{array}$ & $\begin{array}{l}1.994 \\
(4.37)\end{array}$ & $\begin{array}{l}1.812 \\
(4.19)\end{array}$ & $\begin{array}{l}2.139 \\
(4.41)\end{array}$ & $\begin{array}{l}1.777 \\
(3.62)\end{array}$ & $\begin{array}{l}2.502 \\
(5.10)\end{array}$ & $\begin{array}{l}2.422 \\
(5.04)\end{array}$ \\
\hline Log population density of buildout area & $\begin{array}{l}0.237 \\
(2.70)\end{array}$ & $\begin{array}{l}0.241 \\
(3.20)\end{array}$ & $\begin{array}{l}0.258 \\
(3.64)\end{array}$ & $\begin{array}{l}0.252 \\
(3.13)\end{array}$ & $\begin{array}{l}0.204 \\
(2.55)\end{array}$ & $\begin{array}{l}0.278 \\
(3.01)\end{array}$ & $\begin{array}{l}0.273 \\
(3.04)\end{array}$ \\
\hline $\begin{array}{r}\text { Ten-year population growth } 1990 \text { to } \\
1999\end{array}$ & $\begin{array}{l}3.718 \\
(3.65)\end{array}$ & $\begin{array}{l}3.353 \\
(3.78)\end{array}$ & $\begin{array}{l}2.139 \\
(2.42)\end{array}$ & $\begin{array}{l}3.644 \\
(3.85)\end{array}$ & $\begin{array}{l}2.264 \\
(2.24)\end{array}$ & $\begin{array}{l}3.866 \\
(3.77)\end{array}$ & $\begin{array}{l}3.716 \\
(3.71)\end{array}$ \\
\hline $\begin{array}{r}\text { Microwave links/hundred million people } \\
1994\end{array}$ & $\begin{array}{l}-0.021 \\
(2.47)\end{array}$ & $\begin{array}{l}-2.375 \\
(3.16)\end{array}$ & $\begin{array}{l}-1.857 \\
(2.67)\end{array}$ & $\begin{array}{l}-2.605 \\
(3.14)\end{array}$ & $\begin{array}{l}-2.133 \\
(2.73)\end{array}$ & $\begin{array}{l}-1.694 \\
(2.00)\end{array}$ & $\begin{array}{l}-1.507 \\
(1.81)\end{array}$ \\
\hline Log of 1994 population & $\begin{array}{l}0.187 \\
(1.90)\end{array}$ & $\begin{array}{l}0.131 \\
(1.54)\end{array}$ & $\begin{array}{l}0.135 \\
(1.70)\end{array}$ & $\begin{array}{l}0.109 \\
(1.17)\end{array}$ & $\begin{array}{l}0.162 \\
(1.82)\end{array}$ & $\begin{array}{l}0.202 \\
(2.06)\end{array}$ & $\begin{array}{l}0.226 \\
(2.34)\end{array}$ \\
\hline $\begin{array}{l}\text { Fraction of households with annual } \\
\text { income }>\$ 35 \mathrm{k}\end{array}$ & $\begin{array}{l}0.679 \\
(1.00)\end{array}$ & $\begin{array}{l}0.542 \\
(0.93)\end{array}$ & $\begin{array}{l}0.479 \\
(0.87)\end{array}$ & $\begin{array}{l}0.544 \\
(0.87)\end{array}$ & $\begin{array}{l}0.639 \\
(1.04)\end{array}$ & $\begin{array}{l}0.278 \\
(0.34)\end{array}$ & $\begin{array}{l}0.349 \\
(0.49)\end{array}$ \\
\hline Dollar winnings of marginal bidder & & $\begin{array}{l}-0.100 \\
(1.22)\end{array}$ & $\begin{array}{l}-0.098 \\
(1.32)\end{array}$ & $\begin{array}{l}-0.218 \\
(1.82)\end{array}$ & $\begin{array}{l}-0.130 \\
(1.38)\end{array}$ & & \\
\hline Dollar winnings of winning bidder & & & & & & $\begin{array}{l}0.193 \\
(1.54)\end{array}$ & $\begin{array}{l}0.216 \\
(1.76)\end{array}$ \\
\hline $\begin{array}{r}\text { Absolute synergy of marginal bidder } \\
\text { (excluding cellular) }\end{array}$ & & $\begin{array}{l}0.030 \\
(4.01)\end{array}$ & & & & & \\
\hline $\begin{array}{r}\text { Absolute synergy of marginal bidder } \\
\text { (including cellular) }\end{array}$ & & & $\begin{array}{l}0.033 \\
(4.85)\end{array}$ & & & & \\
\hline $\begin{array}{l}\text { Relative synergy of marginal bidder } \\
\text { (excluding cellular) }\end{array}$ & & & & $\begin{array}{l}0.886 \\
(3.03)\end{array}$ & & & \\
\hline $\begin{array}{r}\text { Relative synergy of marginal bidder } \\
\text { (including cellular) }\end{array}$ & & & & & $\begin{array}{l}0.679 \\
(3.33)\end{array}$ & & \\
\hline $\begin{array}{l}\text { Absolute synergy of winning bidder } \\
\text { (excluding cellular) }\end{array}$ & & & & & & $\begin{array}{r}-0.009 \\
(0.81)\end{array}$ & \\
\hline $\begin{array}{r}\text { Absolute synergy of winning bidder } \\
\text { (including cellular) }\end{array}$ & & & & & & & $\begin{array}{l}-0.019 \\
(1.68)\end{array}$ \\
\hline Constant & $\begin{array}{l}-3.960 \\
(2.74)\end{array}$ & $\begin{array}{l}-2.899 \\
(2.30)\end{array}$ & $\begin{array}{l}-2.931 \\
(2.49)\end{array}$ & $\begin{array}{l}-2.657 \\
(1.92)\end{array}$ & $\begin{array}{l}-2.952 \\
(2.22)\end{array}$ & $\begin{array}{l}-4.554 \\
(3.10)\end{array}$ & $\begin{array}{l}-4.761 \\
(3.32)\end{array}$ \\
\hline Adjusted $\mathrm{R}^{2}$ & 0.599 & 0.706 & 0.741 & 0.664 & 0.677 & 0.610 & 0.630 \\
\hline
\end{tabular}

Notes: Excluding Alaska, Guam and American Samoa. Sample size is 48. t-statistics in parenthesis. 
TABLE 7. PRICE REGRESSION INCLUDINGSYNERGIES FOR C AUCTION

\begin{tabular}{|c|c|c|c|c|c|}
\hline \multirow[b]{2}{*}{ Variable } & \multicolumn{5}{|c|}{ Log of Price (\$ per person) } \\
\hline & (1) & (2) & (3) & (4) & $(5)$ \\
\hline Eligible bidders'upfronts/total upfronts & $\begin{array}{l}1.564 \\
(1.38)\end{array}$ & $\begin{array}{l}1.237 \\
(1.11)\end{array}$ & $\begin{array}{l}1.331 \\
(1.19)\end{array}$ & $\begin{array}{l}1.457 \\
(1.29)\end{array}$ & $\begin{array}{l}1.597 \\
(1.40)\end{array}$ \\
\hline Log population density of buildout area & $\begin{array}{l}0.124 \\
(5.27)\end{array}$ & $\begin{array}{l}0.127 \\
(5.52)\end{array}$ & $\begin{array}{l}0.120 \\
(5.18)\end{array}$ & $\begin{array}{l}0.120 \\
(5.12)\end{array}$ & $\begin{array}{l}0.124 \\
(5.21)\end{array}$ \\
\hline Ten-year population growth 1990 to 1999 & $\begin{array}{l}1.581 \\
(5.85)\end{array}$ & $\begin{array}{l}1.492 \\
(5.58)\end{array}$ & $\begin{array}{l}1.516 \\
(5.63)\end{array}$ & $\begin{array}{l}1.551 \\
(5.74)\end{array}$ & $\begin{array}{l}1.580 \\
(5.83)\end{array}$ \\
\hline $\begin{array}{r}\text { Microwave links/hundred million people } \\
1994\end{array}$ & $\begin{array}{l}0.009 \\
(0.08)\end{array}$ & $\begin{array}{r}-0.013 \\
(0.12)\end{array}$ & $\begin{array}{l}-0.009 \\
(0.08)\end{array}$ & $\begin{array}{l}0.015 \\
(0.13)\end{array}$ & $\begin{array}{l}0.010 \\
(0.09)\end{array}$ \\
\hline Log of 1994 population & $\begin{array}{l}0.251 \\
(8.40)\end{array}$ & $\begin{array}{l}0.246 \\
(8.25)\end{array}$ & $\begin{array}{l}0.260 \\
(8.60)\end{array}$ & $\begin{array}{l}0.242 \\
(7.54)\end{array}$ & $\begin{array}{l}0.248 \\
(7.72)\end{array}$ \\
\hline $\begin{array}{l}\text { Fraction of households with annual income > } \\
\qquad 35 \mathrm{k}\end{array}$ & $\begin{array}{l}1.179 \\
(3.71)\end{array}$ & $\begin{array}{l}1.253 \\
(4.02)\end{array}$ & $\begin{array}{l}1.161 \\
(3.70)\end{array}$ & $\begin{array}{l}1.193 \\
(3.76)\end{array}$ & $\begin{array}{l}1.176 \\
(3.69)\end{array}$ \\
\hline Log of MTA price (\$ per person in 1994) & $\begin{array}{l}0.116 \\
(2.79)\end{array}$ & $\begin{array}{l}0.113 \\
(2.75)\end{array}$ & $\begin{array}{l}0.106 \\
(2.54)\end{array}$ & $\begin{array}{l}0.114 \\
(2.73)\end{array}$ & $\begin{array}{l}0.116 \\
(2.78)\end{array}$ \\
\hline GSM technology in MTA & $\begin{array}{r}-0.066 \\
(1.41)\end{array}$ & $\begin{array}{l}-0.068 \\
(1.47)\end{array}$ & $\begin{array}{l}-0.071 \\
(1.52)\end{array}$ & $\begin{array}{l}-0.057 \\
(1.20)\end{array}$ & $\begin{array}{l}-0.066 \\
(1.40)\end{array}$ \\
\hline Dollar winnings of marginal bidder & & $\begin{array}{r}-0.013 \\
(0.63)\end{array}$ & $\begin{array}{l}-0.025 \\
(1.11)\end{array}$ & & \\
\hline Dollar winnings of winning bidder & & & & $\begin{array}{l}-0.002 \\
(0.12)\end{array}$ & $\begin{array}{l}0.007 \\
(0.31)\end{array}$ \\
\hline Absolute synergy of marginal bidder & & $\begin{array}{l}0.016 \\
(4.49)\end{array}$ & & & \\
\hline Relative synergy of marginal bidder & & & $\begin{array}{l}0.385 \\
(3.64)\end{array}$ & & \\
\hline Absolute synergy of winning bidder & & & & $\begin{array}{l}0.008 \\
(1.97)\end{array}$ & \\
\hline Relative synergy of winning bidder & & & & & $\begin{array}{l}-0.008 \\
(0.10)\end{array}$ \\
\hline Constant & $\begin{array}{l}-3.152 \\
(2.87)\end{array}$ & $\begin{array}{l}-2.927 \\
(2.70)\end{array}$ & $\begin{array}{l}-3.040 \\
(2.79)\end{array}$ & $\begin{array}{l}-3.013 \\
(2.74)\end{array}$ & $\begin{array}{l}-3.136 \\
(2.83)\end{array}$ \\
\hline Adjusted $\mathrm{R}^{2}$ & 0.531 & 0.549 & 0.542 & 0.533 & 0.529 \\
\hline
\end{tabular}

Notes: Excluding Alaska, Guam and American Samoa. Sample size is 487. t-statistics in parenthesis. 


\section{Figure 1}

\section{Winning Bidders and Sample Footprints in MTA Broadband PCS Auction*}

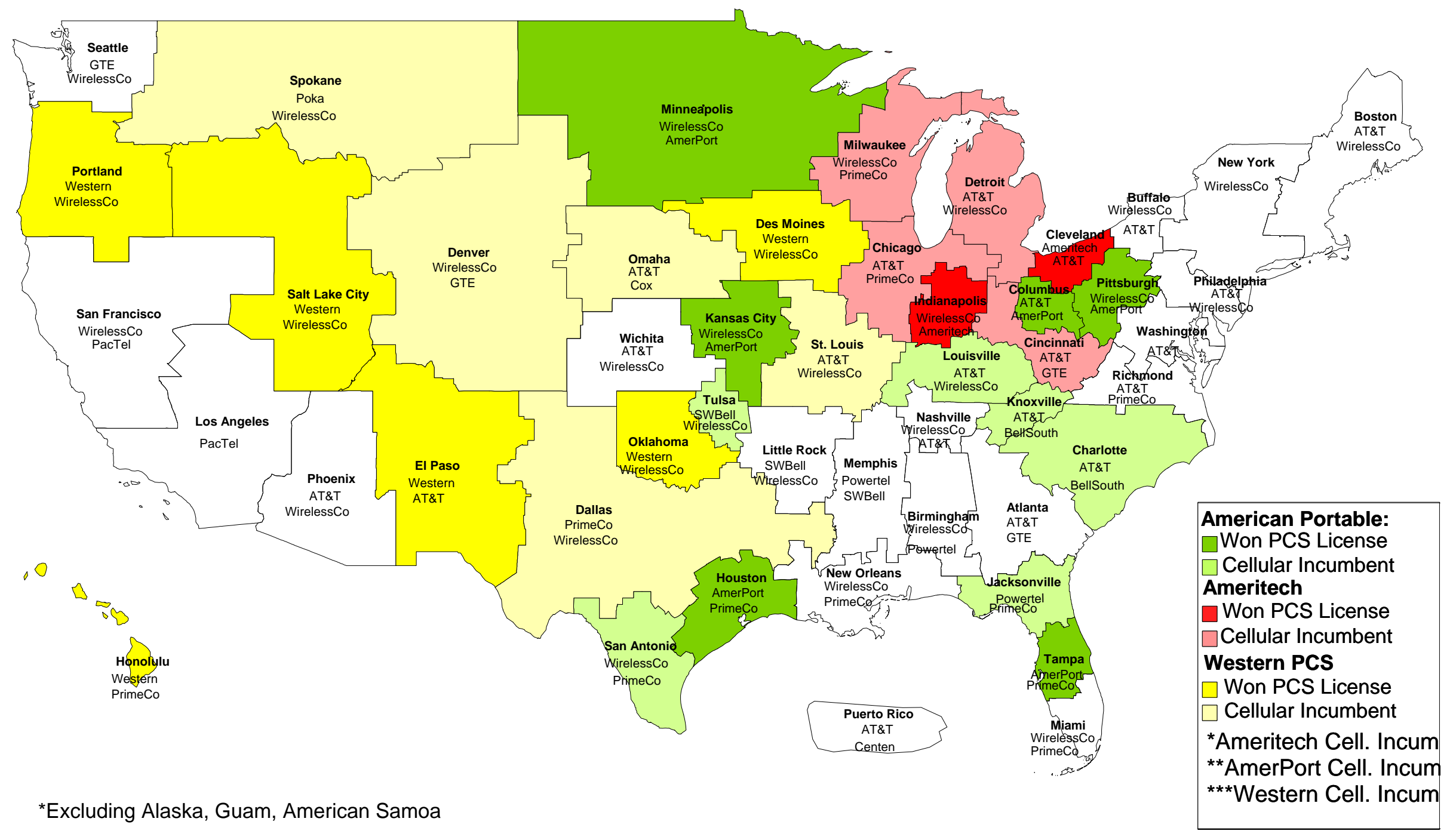




\section{Figure 2}

Footprints of Top-10 Bidders in C-Block Broadband PCS Auction

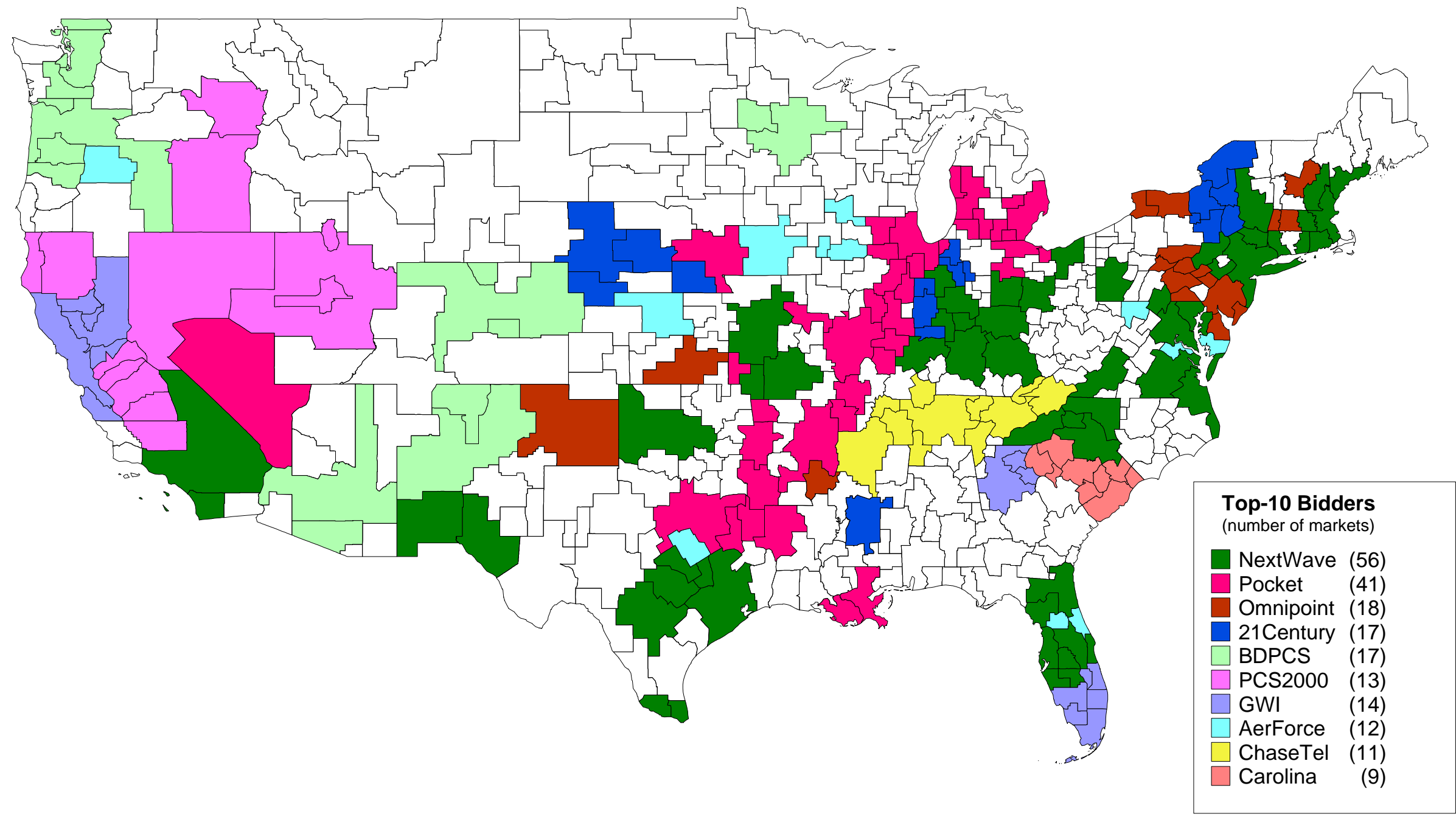




\section{Figure 3 \\ Footprint of WirelessCo \\ in MTA Broadband PCS Auction*}

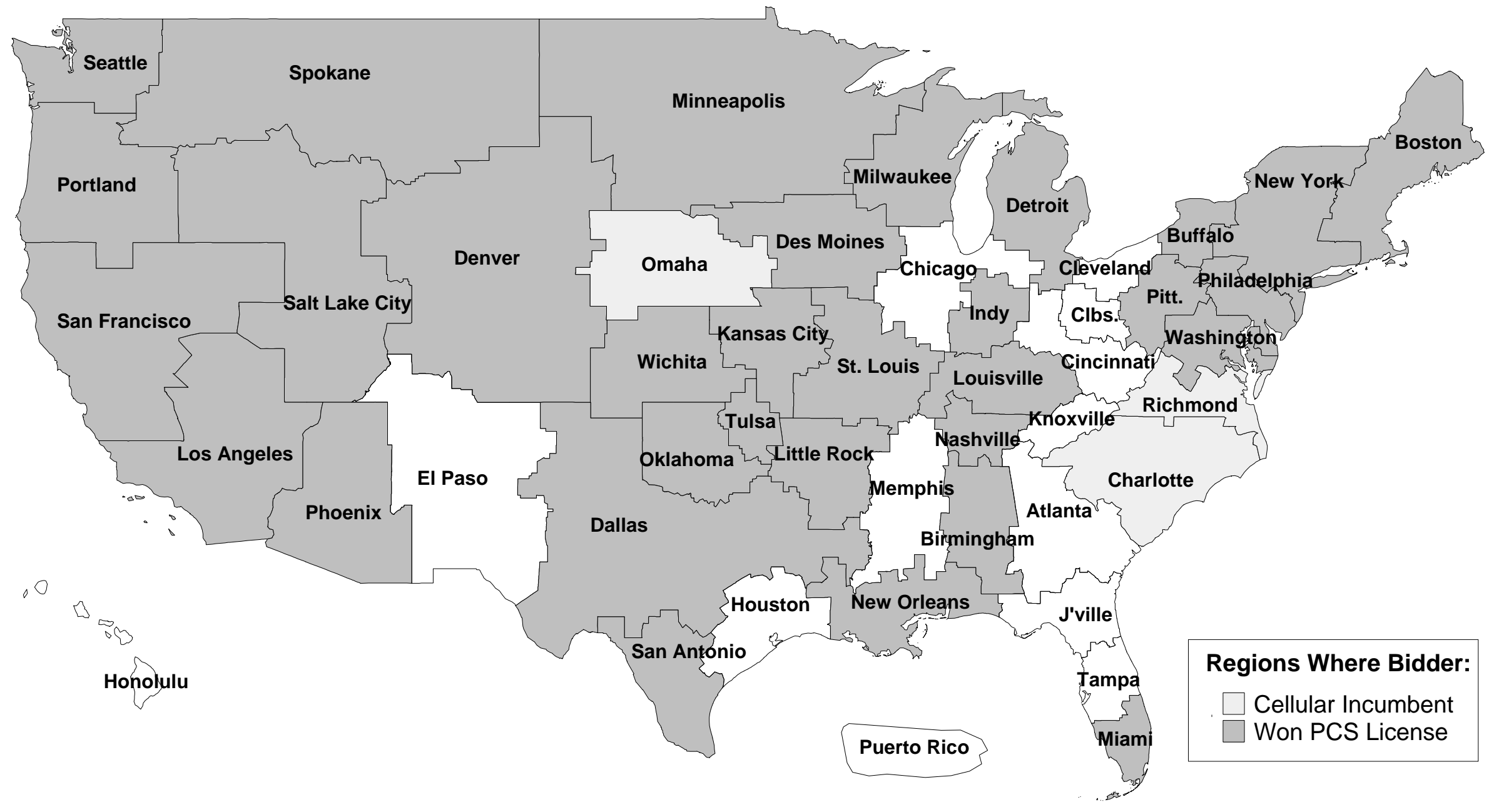




\section{Figure 4 \\ Footprint of AT\&T \\ in MTA Broadband PCS Auction*}

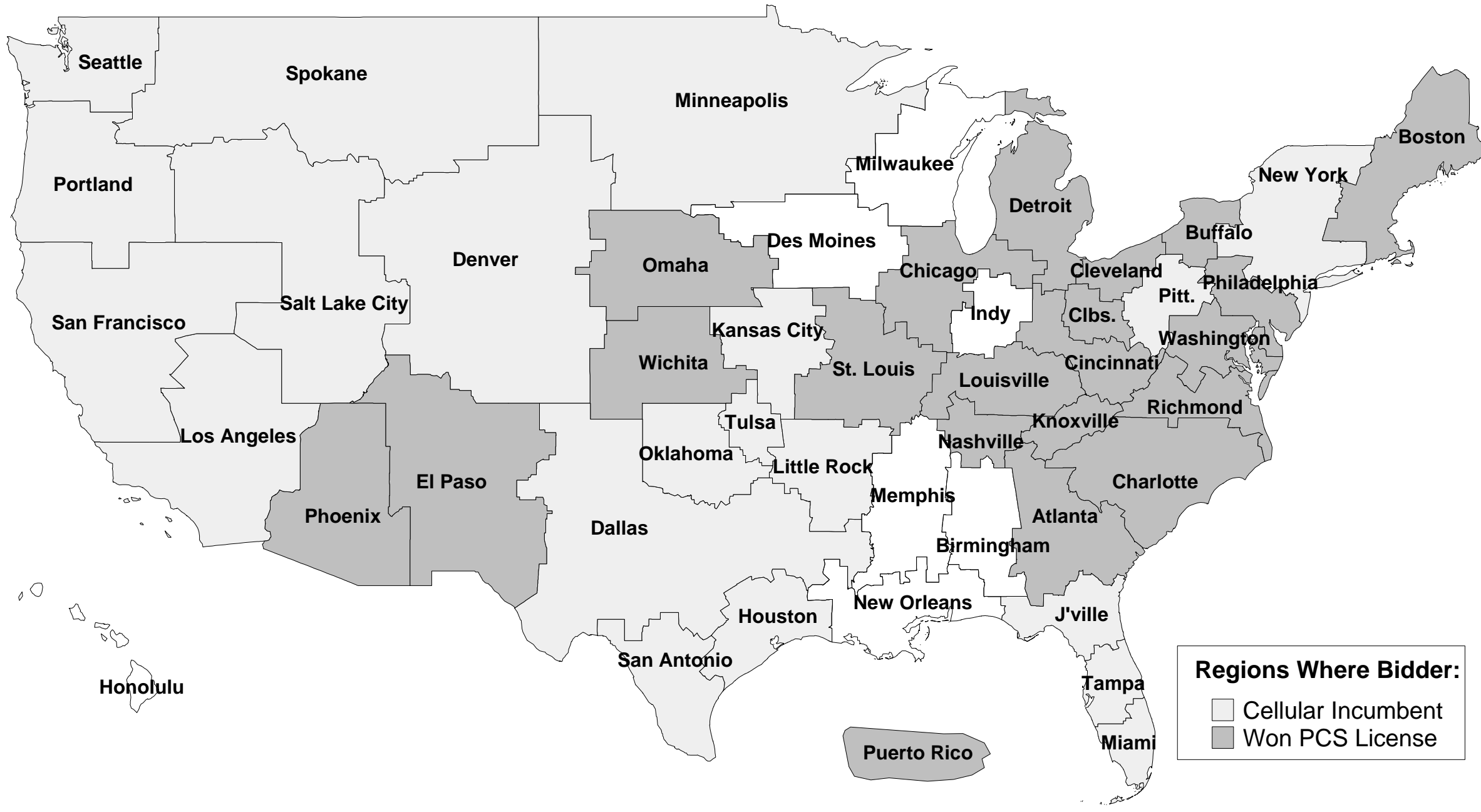

*Excluding Alaska, Guam, American Samoa 


\section{Figure 5 \\ Footprint of PCS PrimeCo in MTA Broadband PCS Auction*}

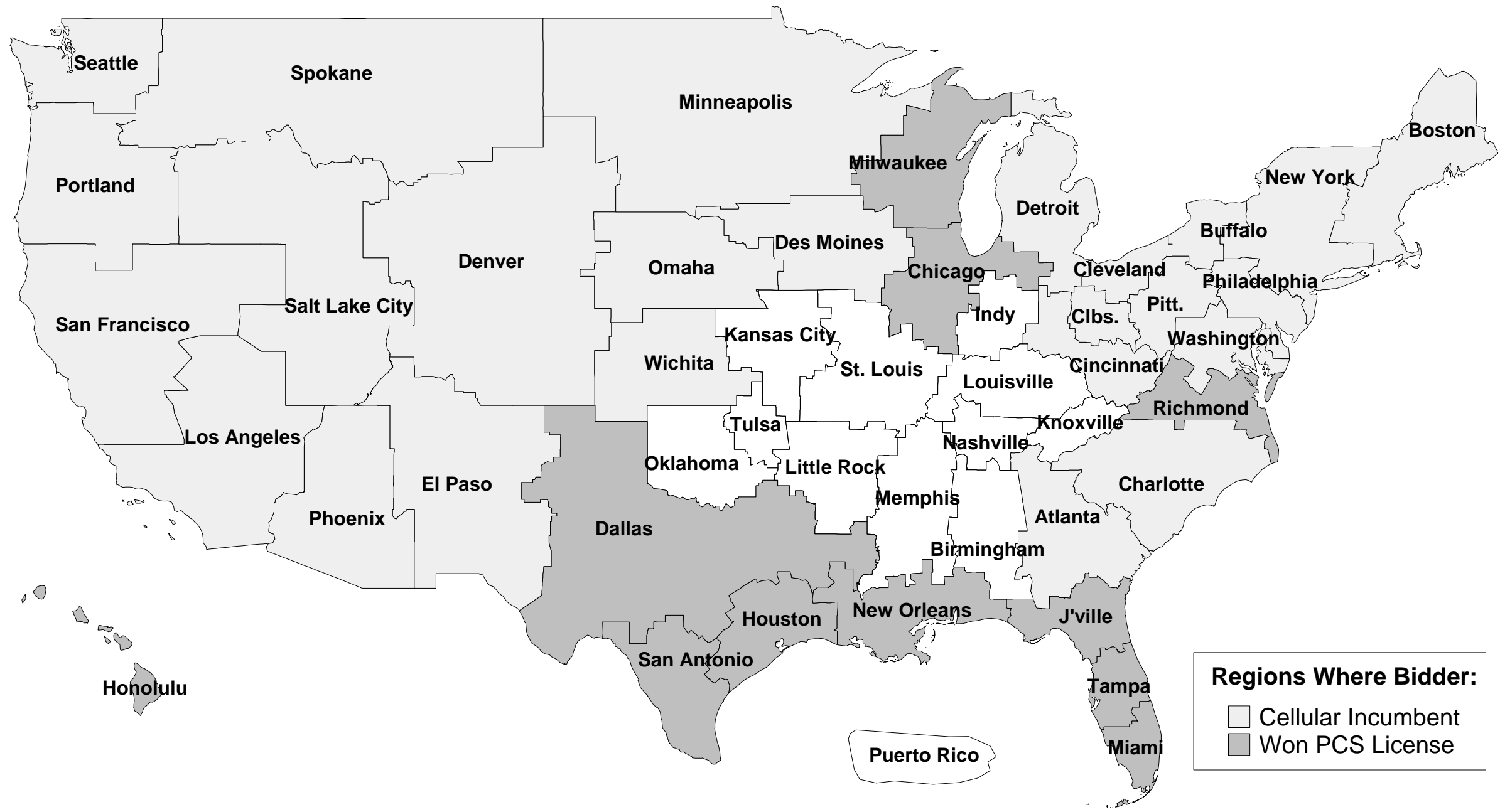

*Excluding Alaska, Guam, American Samoa 